MARTIN, F. "Transnational dream, transnational practice: Tracking women students in Asia's knowledge diasporas." Extended review essay of Youna Kim, Transnational Migration, Media and Identity of Asian Women: Diasporic Daughters. Inter-Asia Cultural Studies 14.3 (Sep 2013): 468-475.

\title{
Accepted draft
}

Review essay on Youna KIM (2011) Transnational Migration, Media and Identity of Asian Women: Diasporic Daughters, New York and London: Routledge. ISBN: 9780-415-89038-0.

Women are on the move in Asia, and they are moving in new ways. Globally, women constitute a growing proportion of transnational migrants (Jones 2008); moreover, the reasons for their migration are changing. Since the mid-1980s, there has been a worldwide increase in women travelling on their own to seek educational and career-advancement opportunities, rather than as legal appendages of husbands (Ho 2006). In northeast Asia this trend is particularly marked. Simultaneous with and related to the rise in women's transnational mobility, patterns of gendered social life are shifting in northeast Asian societies. With high rates of women's education and labour participation and notable trends toward delayed marriage among urban women, women in their twenties and thirties are increasingly seeing themselves as individualized subjects, drawing away from the familial obligations that centrally defined women's social identity for previous generations (Kim ed. in press 2012; Yan 2010: 133-54). In China's post-socialist economy, for example, market capitalism is creating new formations of feminine gender identity based not on family or work-unit ties but instead on labour-market value and recreational consumption (Yan 2010; Rofel 2007; Chen 2008). The younger generation of educated urban women increasingly cherish dreams of wealth, freedom and individual happiness achieved 
through consumption, travel, and a self-scripted life project (Rofel 2007: 111-134). These dreams are often focused through a transnational imaginary constructed in part through women's consumption of Euro-American media.

What are the subjective and material experiences of geo-cultural mobility for this hyper-mobile generation of young northeast Asian women? What happens when such optimistic, outward-focused "diasporic daughters" become physically mobile through educational travel outside Asia? How does the transnational imagination that shapes their dreams at home translate into practice in migration? Does educational mobility result in the formation of the kinds of cosmopolitan identity toward which the travellers aspired before departure? And what will transnational travel mean for young women's gendered identifications — already in flux in a period of far-reaching socio-cultural change in the northeast Asian societies they come from? These are the central questions explored in Youna Kim's meticulously researched and highly thought-provoking new book, Transnational Migration, Media and Identity of Asian Women.

This book presents an in-depth ethnographic study of the Asian "knowledge diaspora" into British higher education, grounded in Kim's three-year interviews- and diaries-based research with sixty women from South Korea, Japan and PRC China who studied in London. Following an introductory chapter and a scene-setting chapter mapping the emergence of a feminized knowledge diaspora from the three nations in question, Chapter 3 presents a discussion of interviewees' motivations for study abroad. It analyses their understandings of "the West"- based on their consumption of Anglophone entertainment media — as a place of freedom from the various problems of their home societies, including family pressures and limited opportunity in local job markets. The following four chapters deal with aspects of interviewees' 
experience after relocation to London: banal racism and "unspeakable exclusion" (Chapter 4); progressive disengagement from the western media that they enjoyed pre-departure, diasporic re-engagement with homeland media, and the consolidation of defensive ethno-nationalism in response to an often hostile British society (Chapter 5); their ultimate disbelief in the possibility of cosmopolitan identification (Chapter 6); and their ambivalence about where to go and what to do next, after their studies (Chapter 7, also incorporating a summary/ conclusion).

As this précis illustrates, the collective story that emerges from Transnational Migration is a very sobering one. Young women who started out in Asia cherishing dreams of "the West" as the locus of personal freedom and self-authorizing individuality end up disappointed and discouraged when faced with British society's reactions toward them, which range from polite disinterest to open hostility and racist violence. As a result, an outward-focussed, proto-cosmopolitan disposition based on an optimistic transnational imaginary transforms into defensive ethno-nationalismeven as the experience of having lived overseas makes the prospect of returning "home" at times equally difficult to imagine as remaining in Britain. This clear disjuncture between the dream and the reality of educational travel is an extremely significant finding, enabled in large part by the astute study design (interviewing women pre-departure as well as whilst in London). The strength of Kim's findings in this respect has major implications. Such work could (and should) spur concrete policy reforms in student-destination nations like the UK and Australia, whose government-defunded higher education systems currently derive such significant support from International students from Asia and yet which have generally failed to make effective or far-reaching enough provisions for safeguarding these students' social wellbeing (Marginson et al 2010). 
Transnational Migration is a fascinating book not just due to the thoroughness of the research and the inherent interest of its topic and findings, but also for its genuinely innovative inter-disciplinarity. Straddling media studies, qualitative sociology and globalization studies in both its themes and its methods, Kim's book brings macro-sociological theory to bear on media as social practice, via an empirical study of the gendered socio-cultural experience of educational migration. Central to the book's conceptual apparatus is a gender-refitted version of the sociological theory of individualization as a key characteristic of social life in late-modern societies. This is an ongoing theoretical concern for Kim: it informed her earlier book, Women, Television and Everyday Life in Korea (2006) and also provides a central rubric in her new edited collection, Women and the Media in Asia: The Precarious Self (in-press 2012). Kim draws on classic theories of late modern social identity from Beck, BeckGernsheim, Giddens and others, who propose that since the late twentieth century, social life has been increasingly centred on an individualized subject (Beck \& BeckGernsheim 2002; Giddens 1992). Late capitalism "frees" the individual from older forms of collective social organization like kinship and class, so the theory goes, leaving her newly open to both the opportunities and the risks associated with this enforced liberation. For women, individualization equates to a transition from "living for others" to "a life of one's own" following specific social transformations: increases in women's education and labour participation, and the impact of feminism and the sexual revolution on sexual morality and cross-sex relationships (Beck \& Beck-Gernsheim 2002: 54-84).

This theory has been elaborated largely in a European social and historical context, and even there it is subject to fierce critique from critical scholars of gender and class (see for example Tomlinson 2003). But rather than mistaking European 
social theory for Asian social fact, Kim centres questions about individualization as an imaginative project, focusing on the disjuncture between young women's dreams of "living for themselves" and their actual social situation where constrained opportunities prevent them from achieving individualized identity. She writes:

Educated women have a strong interest in the idea of individualization, autonomous choice and the aspiration for self-actualization; however, interest in individualization is a growing response not to the successful actualization of that aspiration, but to the frustrated desire for subjective autonomy that is increasingly felt in the "no-choice" situation. [...] A contradiction lies at the heart of female individualization. The individualization of life experiences may reflect a discursive shift in the ways women in today's age "imagine" and "talk" about their lives, rather than a substantive change in actual life conditions, regulative dimensions of gender and social structure which continue to shape available opportunities and constrain personal choice and freedom (5-6).

Bearing out this logic, Chapter 3 frames Korean, Japanese and Chinese women's consumption of transnational media (Sex and the City; Desperate Housewives; Notting Hill) as symptomatic of a yearning toward female individualization that bespeaks a deep dissatisfaction with their own limited opportunities in their home societies. According to this argument, Anglophone media narratives about individualized women characters become imaginative resources for female viewers in Asia, enabling them to articulate their own dissatisfactions to themselves and imagine a utopian alternative. This is both a highly persuasive analysis and an immensely 
refreshing approach to the question of social individualization, recognizing as it does the effects of individualization as a set of transnationally mobile discourses (as well as or instead of concrete social facts), and effectively teasing out the complexities of these discourses' strong attractive power in locations beyond those of the media texts' production. Kim's analysis places the question of gender front and centre: this is a neglected factor both in most macro-level theories of social individualization and in many extant studies of International student experience. Transnational Migration is extremely persuasive in linking young women's motivations for educational travel with both their transnational media consumption and the gendered life conditions currently prevalent in the three societies where they have grown up. In these ways, Kim's book provides immensely productive new perspectives on the theory of individualization, transnational student experience, and some of the constitutive tensions within gender regimes in east Asia today. By showing how western popfeminist media products may mean differently outside the geo-cultural contexts of their production, it could also provide a fresh position from which to re-read EuroAmerican feminist critiques of "post-feminist" popular entertainment media (McRobbie 2004).

In focusing on the imaginative dimensions of individualization, Transnational Migration also contributes to a wider conversation about the role of the imagination in transnational processes. Another study of the "West" imagined from the point of view of a contemporary Asian youth culture that springs to mind in this connection is Bobby Benedicto's recent research on the imagination of "gay globality" from the point-of-view of the commercial gay scene in urban Manila (2010). Like Kim, Benedicto traces the trajectory of people's dreams of becoming part of an imagined world of global (indicatively Western) modernity through travel. Like Kim, he too 
finds such dreams rudely interrupted by the shock of racialization on arrival in Western nations like the USA. "The West," it seems, is sometimes of greatest use as a set of ideas rather than a geographic place: when experienced at first hand from the position of travellers and migrants from Asia, the realities of racism and social exclusion lie extremely far from the imaginative promises of freedom and individual autonomy. The entrenched racism of Anglo-dominant western societies is of course not news: what is exciting in work by these scholars is their careful tracking of the micro-processes through which people's imaginings of “other" places are formed, troubled, and transformed through lived transnational social practices including media consumption, travel, and experiences of racism and social exclusion.

Transnational Migration also forms part of what may be becoming a "wave" of in-depth, reflexive ethnographic accounts of International students as a transnational ethnoscape; for example, Vanessa L. Fong's Paradise Redefined (2011), and the series of articles by Francis Leo Collins (2004, 2008a, 2008b, 2009, 2010a, 2010b). Studies like these demonstrate how an in-depth, theoretically informed ethnographic approach to transnational student experience makes a quantum leap beyond the quantitative or survey-based studies so common in the field of international education, to generate detailed analyses of the subjective, human-level experience of educational mobility. In studies like these, transnational students are becoming recognized as a culturally and socially significant mobile population shaping today's globalizing world. Transnational Migration positions its research subjects as active human agents in a mobile ethnoscape that is redefining the very meanings of nation, culture, gender and identity in northeast Asia and beyond. Another area in which Transnational Migration makes an important (and impassioned) intervention is debates around the meaning and value of 
cosmopolitanism. In Chapter 6, Kim seeks to politicise the notion of cosmopolitanism and ground this often abstract concept with reference to the material lived realities of the transnational subjects she studies. The key question for Kim is not so much, "Is cosmopolitanism a good thing?" (the normative moral discourse that underlies much of the concept's academic valorization, she argues), but instead, "Who has access to cosmopolitan selfhood as a possible mode of being?". For, she proposes, "without recognizing the differences depending on situational openness and relational experience in transnational interactions, the term cosmopolitanism functions as a Eurocentric standard and political ideal" (14).

Kim's findings on the meaning of cosmopolitan values among her study participants are extremely interesting. For this group of women, she finds, gendermarked, individualist and consumption-oriented cosmopolitan ideals and aspirations were generated most by their encounters with western media whilst resident in their home countries in Asia. For Kim, "it is individualist cosmopolitanism that fuels [these east Asian] women's imagination of global Others in various cultural sites generating the expression of individuated self' (115). However, the study participants' actual geographic border-crossings produced not, as one might expect, increased levels of cosmopolitan identification, but instead suspicion and critique of the concept, and the development of what Kim sees as the opposite tendency: a turn toward ethnonationalism. Expressing sentiments broadly representative of the participants' experience of British society as revealed in the book, one Korean interviewee reflected as follows on the topic:

I will always be a foreigner. I feel so alone (in London). There is a boundary like a wide river between us and them, which cannot be crossed. ... We just 
hear people in the classroom talk about cosmopolitanism. We just listen.

Whatever that means, it is their idea. We never invented cosmopolitanism. If it means following them, losing our own identity, it is meaningless to desire that. (117)

Given the levels of social exclusion that these young women experienced in London, it is not surprising that celebratory Euro-American theories on the value of cosmopolitanism as a social project would appear to them as little more than a bad joke. It is not, Kim underlines, that the women did not want to engage in cosmopolitanism, but rather that "many of them come to feel and accept that they cannot afford a cosmopolitan identity $[\ldots]$ in an uneven and highly contested transnational social field" where stubborn hierarchies of race exclude them from meaningful social participation (136).

Kim's findings on waning cosmopolitan aspiration and rising ethnonationalism in diaspora speak interestingly to other recent work on transnational mobility, cosmopolitan orientation, and nationalism among mainland Chinese students (of Kim's three mobile ethnoscapes, this is the one with which this reviewer is most familiar). While Kim finds - persuasively, based on the quoted testimony of the participants - that there was quite a marked opposition between pre-departure cosmopolitan orientation and rising ethno-nationalism in diaspora, this differs from the conclusion reached by some other scholars working on related questions. Lisa Rofel, for example (cited by Kim in her section on Chinese women and cosmopolitanism), proposes that within China, young, heterosexual women's identity is framed through a consumer-cosmopolitanist discourse that enables them to imagine transcending (Chinese) locality while simultaneously reworking Chineseness as 
cosmopolitan: a double move that Rofel calls "cosmopolitanism with Chinese characteristics" (2007: 111-134). "The contradiction of transcending China to become a cosmopolitan self and domesticating cosmopolitanism within China rests [...] in the bodies of young women" (2007: 129-30). In her study of a large cohort of Chinese transnational students' experience worldwide, meanwhile, Vanessa Fong (2011) observes a related orientation in her research subjects. Out of a strong and ongoing sense of "filial nationalism," the students she spoke with wanted to re-imagine and remake China as part of the "developed world" to whose cultural and social citizenship they aspired through their educational travels:

They believed that pilgrimages to developed countries would not only help them become citizens of the developed world but also facilitate efforts to make China part of the developed world. Ideally, developed world citizenship would add to rather than replace their Chinese citizenship. (Fong 2011: 6)

Fong's findings on the students' post-study perspectives on China, the "developed world" and cosmopolitan orientation are more complex and multivalent than Kim's. Most of the people in her study found that studying overseas led to heightened ambivalence about both China and the "developed world" (220). In part, Fong echoes Kim's emphasis on students' experiences of discrimination overseas and consequent heightened nationalism. But she also underscores that the aspiration to actualize developed world citizenship within China post-overseas study, thereby cosmopolitanizing both themselves and China itself, does appear to have been realizable for at least some of the students interviewed (191-220). Overall, the picture that emerges is one of a complex layering of national(ist) with cosmopolitan 
orientations and identifications, rather than any simple opposition between the two terms.

In an article that frames the relationship between cosmopolitan and nationalist identification among Chinese overseas students as its central problematic, Pál Nyíri, Juan Zhang and Merriden Varrall focus on the collective patriotic responses by Chinese students worldwide to various incidents connected with the 2008 Beijing Olympics. In light of the several waves of nationalist demonstrations by a generation of young, fashionable, middle-class, consumerist, transnational Chinese students that year, the authors - sharing something in common with the conclusions of Rofel and Fong, cited above - argue that nationalism does not stand in opposition to a Chinese cosmopolitan youth identity, but that "hip nationalism" is in fact an integral part of that identity (27). They propose that:

As much as it offers a cathartic emotional experience of identifying with the nation (and more particularly, with millions of fellow nationalist youth worldwide), [hip nationalism] also provides an opportunity for individual demonstrations of middle-class sophistication, creativity, passion, youthful power and cosmopolitanism. For young demonstrators overseas, these attributes represent not only an ideal self but also the new "real China" (as opposed to the caricature painted by Western media), and they see themselves as cosmopolitan nationalists who spearhead and embody this new nation. (ibid.)

Both the strong affective response at seeing China "misrepresented" in Western media and the consolidation of ethno-nationalist orientations in diaspora are 
observations common across Kim's, Fong's, and Nyíri, Zhang and Varrall's studies. What differ significantly are their interpretations: for Kim, the solidification of ethnonationalist orientation replaces a former (proto-)cosmopolitan disposition, while for Fong and Nyíri, Zhang and Varrall (as for Rofel), ethno-nationalism is part of Chinese cosmopolitan youth identity_including in diaspora. This difference may be explainable in light of the different contexts and different questions focussed upon in the various studies. Possibly, however, it may also have to do with the specificity of cultural identification among youth from China. In many respects, as Kim's book illustrates so persuasively, it makes a lot of sense to study the experience of Chinese women students alongside those of women students from Korea and Japan. But further consideration of the specificities of PRC Chinese (and Korean, and Japanese) identifications could also be of value. It is possible that at the current historical juncture, with China's economic growth and the hyper-awareness within China of the nation's rising status in the global power hierarchy and increasing centrality to global systems, national(ist) identification among youth from China is able to fold within itself associations with cosmopolitan transcendence in ways that Japanese and Korean national identifications cannot. Rofel's broader argument certainly suggests such an idea: she observes that over the last two decades in China, there has emerged a pervasive discourse constructing a desired (and desiring) cosmopolitan worldliness based on a universal human nature (2007: 3). This cosmopolitan worldliness is not constructed as Other to the Chinese nation. On the contrary, widespread appeals to "human nature" and desire within China construct a re-imagined (young) Chinese identity as part of, indeed as representative of, such worldliness (2007: 119). Thus, for young Chinese women, cosmopolitanism cannot be seen as simply opposed to either the local or the national (2007: 133; Fong 2011: 65). 
To extrapolate further and put all of this in slightly different terms: speculatively, such studies would suggest that the social marginalization of PRC Chinese students in Euro-American nations may not easily overwhelm this generation's inner sense of China's destined place at the centre of a future world system. The studies cited above imply that for this generation, nationalism is cosmopolitanism in a way that is probably not the case for students from Japan or Korea. Further pursuing this line of thought, Kim's provocative discussions on cosmopolitanism versus nationalism could form the basis for a fresh conversation on the multiple meanings of "cosmopolitanism" in transnational east Asian contexts. For clearly enough, "cosmopolitanism with Chinese characteristics" differs from the kind of idealist, nation-transcending cosmopolitanism that is championed in the dominant European theory. Both of these are different again from the feminized consumercosmopolitanism emblematized in transnational entertainment media (two of Kim's Korean interviewees immediately associated the word "cosmopolitan" with the international US-based women's magazine of that title, and with Carrie's signature cocktail in Sex and the City). In different contexts, subjects can be interpellated by one (or more) of these versions of cosmopolitanism while simultaneously being excluded by another.

Placing greater emphasis on the plurality of cosmopolitanisms and their different meanings and effects in geo-cultural context would help to productively complicate the simple opposition that Kim sometimes falls back on between nationalism and cosmopolitanism. In Chapter 6, for example, she acknowledges a contradictory process in her Chinese interviewees in London, where a heightened Chinese-national identification was "wrapped in a more conspicuous cosmopolitan consumer culture" (131). Yet ultimately, rather than working with this hybrid 
identification, she appears to discard their consumer-cosmopolitanism as merely a "thin," superficial cover for a "thick" and "profound process of nationalism" (132). Nationalism may amount to the opposite of some formations of cosmopolitanism, but as we have seen, at least in the case of Chinese cultural identifications, this may not necessarily or always be the case. What if we see consumer-cosmopolitanism (or other forms of cosmopolitanism) as folded within Chinese youth nationalism, rather than as a priori in conflict with it? The provocation to such questions, however, should not be seen as an indication of any substantive weakness in the book. Overall, Kim's critique of the dominant, abstract Eurocentric version of cosmopolitanism— the "unity of mankind" version - remains extremely forceful in light of her study participants' material experiences in Europe. And the fact that this book leads one to see such generative points of intersection and conversation with a range of other works in related fields is certainly testimony to both the strong contemporary relevance of its topic the interest of its analyses.

Overall, Transnational Migration is a very exciting book. Based on detailed empirical research, it mounts spirited interventions across a wide range of areas from sociological theory to international education studies. Throughout, Kim maintains a passionate commitment to engaged social critique based on sophisticated analysis of the study subjects' material social experiences. This book presents extremely important findings about transnational student experience as well as some provocative arguments on concepts from individualization to cosmopolitanism and nationalism. It should be required reading for anyone interested in gender, media and cultural globalization.

\section{Works Cited}


Beck, Ulrich and Elizabeth Beck-Gernsheim (2002) Individualization: Institutionalized Individualism and its Social and Political Consequences, London: Sage.

Benedicto, Bobby (2010) "Bright lights, gay globality: Mobility, class and gay life in twentyfirst century Manila,” PhD dissertation: University of Melbourne.

Chen, Minglu (2008) “Entrepreneurial Women: Personal Wealth, Local Politics and Tradition," in David S. G. Goodman ed., The New Rich in China: Future Rulers, Present Lives, New York: Routledge, 112-125.

Collins, Francis Leo (2004) “(Trans)national Bodies, (Trans)national Languages and the Transformation of Local Urban Space,” New Zealand Geographer 60.1: 52-59. Collins, Francis Leo (2008a) "Bridges to Learning: International Student Mobilities, Education Agencies and Inter-Personal Networks," Global Networks 8.4: 398-417. Collins, Francis Leo (2008b) "Of Kimchi and Coffee: Globalisation, Transnationalism and Familiarity in Culinary Consumption," Social and Cultural Geography 9.2: 151-69. Collins, Francis Leo (2009) “Connecting 'Home' with 'Here': Personal Homepages in Everyday Transnational Lives," Journal of Ethnic \& Migration Studies 35.6: 835589.

Collins, Francis Leo (2010a) "Negotiating Un/Familiar Embodiments: Investigating the Corporeal Dimensions of South Korean International Student Mobilities in Auckland, New Zealand," Population, Space and Place 16.1: 51-62.

Collins, Francis Leo (2010b) "International students as urban agents: International education and urban transformation in Auckland, New Zealand," Geoforum 41: 940-950.

Fong, Vanessa L. (2011) Paradise Redefined: Transnational Chinese Students and the Quest for Flexible Citizenship in the Developed World, Stanford: Stanford University Press. Giddens, Anthony (1992) Modernity and Self-Identity: Self and Society in the Late Modern Age, Stanford: Stanford University Press. 
Ho, Christina (2006) "Women Crossing Borders: The Changing Identities of Professional Chinese Migrant Women in Australia," PORTAL Journal of Multidisciplinary International Studies 3.2: 1-16.

Jones, Adele (2008) “A Silent but Mighty River: The Costs of Women’s Economic Migration," Signs 33.4: 761-769.

Kim, Youna (2006), Women, Television and Everyday Life in Korea: Journeys of Hope, New York and London: Routledge.

Kim, Youna ed. (in press 2012) Women and the Media in Asia: The Precarious Self. New York: Palgrave Macmillan.

Marginson, Simon, Christopher Nyland, Erlenawati Sawir and Helen Forbes-Mewett (2010) International Student Security, Cambridge: Cambridge University Press.

McRobbie, Angela (2004) "Post-feminism and popular culture," Feminist Media Studies 4.3: $255-264$.

Nyíri, Pal, Juan Zhang with Merriden Varrall (2010) "China's Cosmopolitan Nationalists:

"Heroes" And "Traitors" Of the 2008 Olympics," China Journal 63: 25-55.

Rofel, Lisa (2007) Desiring China: Experiments in Neoliberalism, Sexuality, and Public Culture, Durham: Duke University Press.

Tomlinson, Mark (2003) "Lifestyle and Social Class," European Sociological Review 19.1: 97-111.

Yan, Yunxiang (2010) The Individualization of Chinese Society, New York: Berg. 